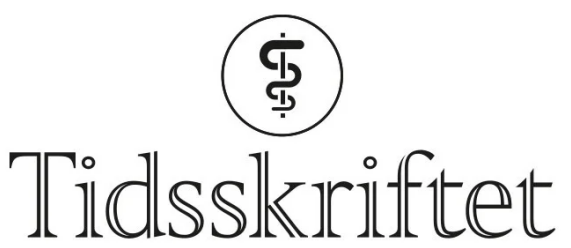

DEN NORSKE LEGEFORENING

\title{
Ønske om nye perspektiv er hverken utdatert eller kunnskapsløst
}

KOMMENTAR

\section{TROND VELKEN}

velt@siv.no

Trond Velken er spesialist i psykiatri og barne- og ungdomspsykiatri og avdelingsoverlege ved BUPA, Sykehuset i Vestfold.

Forfatteren har ikke oppgitt noen interessekonflikter.

Når man ser hvor tungt skyts som avfyres mot Rasmussens lederkommentar (1) om selvmordsforebygging virker det jo tryggest å holde hodet lavt i terrenget. Men som kliniker godt plassert i arbeidet med selvmordsnære pasienter føler jeg likevel behov for å kommentere utsagn fra Mehlum og medarbeidere om at Tidsskiftets lederkommentar er dogmatisk, svakt begrunnet, utdatert og frakoblet kunnskapsgrunnlaget på feltet (ㅁ). Harde ord fra sentrale aktører som heller bør stimulere til og ønske velkommen debatt på et felt hvor få føler at man har kommet i mål.

Jeg leste innlegget fra Rasmussen som en helt betimelig påpekning av at vi trenger et bredere perspektiv på selvmordsforebygging enn den medisinske modellen som har vektlagt psykisk lidelse som den mest sentrale risikofaktoren. Det er hun ikke alene om å mene, noe en nylig gjennomgang i psykologtidsskriftet gjør godt rede for (3). Rasmussen avfeier ikke at psykisk lidelse kan være viktig å oppdage og behandle slik hun beskyldes for, men minner om at dette fokuset kan gå på bekostning av andre viktige perspektiv.

Dersom vi legger Mehlum og medarbeidere sin egen referanse til grunn, viser en nylig metaanalyse fra Too m.fl. at den populasjonsattribuerte risikoen av psykisk lidelse for selvmord er $21 \%$ (4). Dette basert på registerstudier som trolig undervurderer risikoen noe. Like fullt er dette kunnskap som gir god støtte til Rasmussens vektlegging av at andre faktorer enn psykisk lidelse kan ha stor betydning når mennesker tar sitt eget liv. Too gjør i sin gjennomgang rede for at tidligere oppsummeringer kan ha overvurdert hvor stor rolle psykisk lidelse spiller som risikofaktor. Da er det overraskende å lese at Mehlum og medarbeidere karakteriserer Tidsskriftets leder som utdatert.

\section{LITTERATUR}

1. Rasmussen ML. Nye perspektiv på selvmordsforebygging. Tidsskr Nor Legeforen 2020;140. doi: 10.4045/tidsskr.20.0708. [CrossRef] 
2. Mehlum L, Walby F, Johannessen JO et al. Sterke påstander - svakt grunnlag. Tidsskr Nor Legeforen. https://tidsskriftet.no/2020/og/kommentar/sterke-pastander-svakt-grunnlag. Lest 16.o9.2020.

3. Halvorsen P. Splittet i synet på selvmordsforebygging. Tidsskrift for Norsk Psykologforening. https://psykologtidsskriftet.no/nyheter/2020/01/splittet-i-synet-pa-selvmordsforebygging. Lest 16.09.2020.

4. Too LS, Spittal MJ, Bugeja L et al. The between mental disorders and suicide: A systematic review and meta-analysis of record linkage studies. J Affect Disord 2019; 259:302-13. [PubMed][CrossRef]

Publisert: 12. oktober 2020. Tidsskr Nor Legeforen. DOI:10.4045/tidsskr.20.0745

(C) Tidsskrift for Den norske legeforening 2023. Lastet ned fra tidsskriftet.no 26. april 2023. 